\title{
MENGEMBANGKAN DISPOSISI MATEMATIS SISWA SMP MELALUI PENDEKATAN PROBLEM POSING
}

\author{
Cut Man Farisyah \\ SMPN 1 Bandar Baru \\ e-mail: manfarisyahcut@gmail.com
}

\begin{abstract}
ABSTRAK
Pembelajaran matematika tidak hanya bertujuan untuk mengembangkan kemampuan kognitif matematis, tetapi juga untuk mengembangkan ranah afektif. Salah satu aspek penting dalam ranah afektif yang sangat berpengaruh dan ikut menentukan keberhasilan dalam belajar matematika adalah pandangan positif siswa terhadap matematika atau dalam pembelajaran matematika disebut dengan disposisi matematis. Seorang siswa yang memiliki disposisi tinggi akan lebih gigih dan ulet dalam menghadapi masalah matematika yang lebih menantang dan akan lebih bertanggung jawab terhadap belajar mereka sendiri serta selalu mengembangkan kebiasaan baik di matematika. Pendekatan problem posing yang dalam proses pembelajarannya mengharuskan siswa untuk mengajukan soal serta membuat penyelesaiannya diduga akan dapat mengubah pandangan siswa terhadap matematika menjadi lebih positif, disamping juga meningkatkan kemampuan matematis siswa. Penelitian ini bertujuan untuk mengkaji perbedaan tingkatan disposisi matematis siswa SMP sebelum dan sesudah memperoleh pembelajaran melalui pendekatan problem posing. Jenis penelitiannya adalah penelitian eksperimen dengan desain one group pre-test post-test design. Adapun populasi dalam penelitian ini adalah seluruh siswa kelas VII SMPN 1 Bandar Baru, dengan sampel penelitian siswa kelas VII2 yang dipilih melalui teknik random sampling. Instrumen yang digunakan untuk memperoleh data penelitian berupa lembar angket skala disposisi matematis. Uji statistik yang digunakan untuk mengalisis data perbedaan disposisi matematis siswa SMP sebelum dan sesudah memperoleh pembelajaran melalui pendekatan problem posing adalah uji-t berpasangan. Hasil penelitian menunjukkan bahwa terdapat perbedaan yang signifikan tingkatan disposisi matematis siswa SMP sebelum dan sesudah memperoleh pembelajaran melalui pendekatan problem posing. Artinya disposisi matematis siswa menjadi lebih baik setelah mereka memperoleh pembelajaran dengan pendekatan problem posing.
\end{abstract}

Kata kunci: Disposisi Matematis, Pendekatan Problem Posing

\begin{abstract}
Learning mathematics is not only aimed at developing mathematical cognitive abilities, but also for developing affective domains. One important aspect in the affective domain that is very influential and determines success in learning mathematics is the positive view of students on mathematics or in mathematics learning called mathematical disposition. A student who has a high disposition will be more persistent and resilient in facing mathematical problems that are more challenging and will be more responsible for their own learning and always develop good habits in mathematics. The problem posing approach which in the learning process requires students to ask questions and make their solutions is expected to be able to change students 'views of mathematics to be more positive, while also improving students' mathematical abilities. This study aims to examine the differences in the levels of mathematical disposition of junior high school students before and after learning through the problem posing approach. The type of research is experimental research with the design of one group pre-test post-test design. The population in this study were all VII grade students of Bandar Baru 1 Junior High School, with research samples
\end{abstract}


of class VII2 students selected through random sampling techniques. The instrument used to obtain the research data was a mathematical disposition scale questionnaire sheet. The statistical test used to analyze data on differences in mathematical disposition of junior high school students before and after learning through the problem posing approach is paired t-test. The results showed that there were significant differences in the level of mathematical disposition of junior high school students before and after learning through the problem posing approach. This means that students' mathematical dispositions get better after they get a problem posing learning approach.

Keywords: Mathematical Disposition, Problem Posing Approach

\section{PENDAHULUAN}

Selain mengembangkan kemampuan kognitif matematis siswa, pembelajaran matematika juga dimaksudkan untuk mengembangkan ranah afektif. Salah satu aspek penting dalam ranah afektif yang sangat berpengaruh terhadap proses dan hasil belajar siswa adalah pandangan positif siswa terhadap matematika. Hal ini sesuai dengan salah satu tujuan pembelajaran matematika di sekolah yaitu selain memiliki kecakapan terhadap kemampuan matematika, memiliki sikap menghargai kegunaan matematika dalam kehidupan seperti rasa ingin tahu, perhatian, minat dalam mempelajari matematika dan sikap ulet serta percaya diri dalam pemecahan masalah matematika, juga penting dimiliki oleh siswa. Hal yang sama juga terdapat dalam National Council of Teacher of Mathematics (NCTM) tahun 2003 pada poinnya yang ketujuh tentang tujuan pembelajaran matematika yaitu pembentukan sikap positif terhadap matematika. Sikap atau pandangan yang positif terhadap matematika akan sangat berpengaruh terhadap proses dan hasil belajar siswa. Ketika siswa sudah benarbenar menghargai matematika dan merasa bahwa matematika itu bermanfaat dalam kehidupan maka siswa tersebut akan menyelesaikan suatu permasalahan matematika dengan sungguh-sungguh, ulet, penuh rasa percaya diri serta melakukan refleksi atas cara berpikir. Keadaan yang demikian dalam matematika dinamakan dengan disposisi matematis (Karlimah, 2010). Disposisi matematis adalah keterkaitan dan apresiasi terhadap matematika sehingga menimbulkan kecenderungan untuk berpikir dan bertindak dengan cara yang positif (NCTM, 2003).

Disposisi siswa terhadap matematika akan terlihat melalui sikap siswa ketika menyelesaikan tugas matematika, apakah mereka menyelesaikan tugas tersebut dengan tekun, penuh percaya diri serta mempunyai keingintahuan yang tinggi dalam mencarialternatif jawaban dan menemukan penyelesaian yang tepat untuk semua tugas yang diperolehnya. Hal ini sesuai dengan pendapat Katz (1993) yang mengatakan bahwa disposisi matematis berkaitan dengan bagaimana siswa menyelesaikan masalah matematis apakah mereka menyelesaikannya dengan penuh rasa percaya diri, tekun, berminat, dan berpikir fleksibel untuk menemukan berbagai alternatif penyelesaian masalah. Wardani (2011) mendefinisikan disposisi matematis sebagai suatu ketertarikan dan apresiasi terhadap matematika seperti kecenderungan untuk berpikir dan bertindak dengan positif termasuk kepercayaan diri, keingintahuan, ketekunan, antusias dalam belajar, gigih dalam menghadapi permasalahan, fleksibel, mau berbagi dengan orang lain dan reflektif dalam kegiatan matematika. Sedangkan Sumarmo (2010) menyatakan bahwa disposisi matematis adalah keinginan, kesadaran, kecenderungan dan dedikasi yang kuat pada diri siswa atau mahasiswa untuk berpikir dan berbuat secara matematik. Jadi disposisi matematis merupakan suatu apresiasi atau sikap positif siswa dalam memandang matematika sebagai sesuatu yang berguna dalam kehidupan mereka sehingga mereka akan berusaha dengan sungguh-sungguh, ulet dan penuh percaya 
diri untuk mempelajari dan menyelesaikan berbagai masalah matematika.

Siswa memerlukan disposisi matematis untuk bertahan dalam menghadapi masalah, mengambil tanggung jawab dalam belajar, dan mengembangkan kebiasaan kerja yang baik dalam matematika (Mahmudi, 2010). Lebih lanjut Mahmudi (2010) menambahkan bahwa siswa yang memiliki disposisi tinggi akan lebih gigih, tekun, dan berminat untuk mengeksplorasi hal-hal baru. Hal ini memungkinkan siswa tersebut memiliki pengetahuan lebih dibandingkan siswa yang tidak menunjukkan perilaku demikian. Pengetahuan inilah yang menyebabkan siswa memiliki kemampuan-kemampuan tertentu. Dengan demikian dapat dikatakan bahwa disposisi matematis akan menunjang kemampuan matematis lain.

Mengingat pentingnya disposisi matematis atau sikap positif siswa terhadap matematika dalam proses pembelajaran, maka hal ini harus mendapat perhatian serius terutama bagi guru matematika. Hal ini dimaksudkan supaya pembelajaran matematika di sekolah menjadi lebih efektif dan berdaya guna. Akan tetapi, yang terjadi di lapangan selama ini menunjukkan keadaan yang sebaliknya, sebagian besar siswa masih menganggap bahwa matematika merupakan mata pelajaran yang sulit dan kurang bermanfaat dalam kehidupan sehari-hari sehingga mereka tidak begitu menghargai matematika. Abdurrahman mengungkapkan bahwa dari berbagai bidang studi yang diajarkan disekolah, matematika merupakan bidang studi yang dianggap paling sulit oleh siswa, baik siswa yang tidak berkesulitan belajar maupun siswa yang berkesulitan belajar. Pandangan siswa yang negatif terhadap matematika akan berakibat pada berkurangnya minat dan kesungguhan siswa dalam mempelajari dan menyelesaikan masalah matematika sehingga disposisi matematis siswa menjadi rendah. Salah satu penelitian yang mengungkapkan tentang rendahnya disposisi siswa adalah penelitian yang dilakukan oleh Kesumawati (2012) terhadap 297 siswa dari empat SMP di kota
Palembang. Hasil pengisian skala disposisi matematis menunjukkan bahwa persentase perolehan skor rerata disposisi siswa sebesar 58 persen berada pada kategori rendah.

Banyak faktor yang menyebabkan rendahnya kemampuan berpikir siswa dalam proses pembelajaran. Salah satunya adalah pembelajaran yang berpusat pada guru (konvensional) seperti yang sering diterapkan disekolah-sekolah selama ini, dimana peran guru lebih dominan sehinga siswa cenderung pasif (MKBPM, 2001). Oleh karena itu, diperlukan suatu pendekatan pembelajaran yang tepat sehingga dapat mengubah proses pembelajaran dari situasi guru mengajar menjadi situasi siswa belajar atau siswa terlibat aktif dalam proses pembelajaran sehingga siswa lebih mengenal dan menghargai matematika. Prinsip belajar aktif akan dapat menumbuhkan sasaran matematika yang kritis dan kreatif Salah satunya adalah pembelajaran matematika dengan pendekatan problem posing.

Problem posing yang oleh sebagian ahli seperti Silver (1994) dan English (1997) diartikan sebagai pengajuan masalah, adalah salah suatu bentuk pendekatan dalam pembelajaran yang menekankan siswa untuk merumuskan soal dan menyelesaikannya berdasarkan situasi yang diberikan. Pada problem posing siswa diberikan suatu kondisi tertentu dan kemudian siswa diminta untuk mengajukan soal matematika yang berkaitan dengan kondisi tersebut. English (1997) menjelaskan bahwa problem posing penting dalam kurikulum matematika karena didalamnya terdapat inti dari aktivitas matematika dimana siswa membangun masalahnya sendiri. Proses pembelajaran seperti ini sangat menuntut siswa untuk memiliki sikap tekun dan gigih khususnya dalam merancang sebuah soal dan juga penyelesaiannya sehingga siswa akan lebih memahami dan menghargai matematika. Pembelajaran dengan pendekatan problem posing diduga akan dapat meningkatkan disposisi matematis siswa, disamping juga meningkatkan kemampuan matematis siswa. Hal ini sesuai dengan pendapat English 
(1997) yang menyatakan bahwa problem posing atau membuat soal dapat meningkatkan kemampuan berpikir siswa dan dapat membantu siswa dalam mengembangkan keyakinan dan kesukaan terhadap matematika. Dengan demikian, maka yang menjadi rumusan masalah dalam penelitian ini adalah: apakah terdapat perbedaan tingkatan disposisi matematis siswa SMP sebelum dan sesudah memperoleh pembelajaran melalui pendekatan problem posing?

Adapun yang menjadi tujuan dari penelitian ini adalah untuk mengetahui perbedaan tingkatan disposisi matematis siswa SMP sebelum dan

sesudah memperoleh pembelajaran melalui pendekatan problem posing.

\section{METODE PENELITIAN}

Penelitian ini merupakan penelitian eksperimen karena peneliti melakukan pemberian perlakuan terhadap sampel penelitian untuk selanjutnya ingin diketahui pengaruh dari perlakuan tersebut. Perlakuan yang diberikan yaitu penerapan pembelajaran dengan pendekatan problem posing pada sampel penelitian (kelas eksperimen). Desain eksperimen yang digunakan dalam penelitian ini adalah adalah one group pre-test post-test design (Arikunto, 2000). Penelitian ini dilakukan di SMP 1 Bandar Baru. Adapun populasi dalam penelitian ini adalah seluruh siswa kelas VII SMPN 1 Bandar Baru, dengan sampel penelitian siswa kelas VII2 yang dipilih melalui teknik random sampling.

Data pada penelitian ini diperoleh dari instrumen penelitian yaitu berupa lembar angket skala disposisi matematis yang diberikan sebelum dan sesudah proses pembelajaran berlangsung. Lembar angket terdiri dari 40 pernyataan yang diuraikan dari tujuh indikator disposisi matematis tentang sikap dan pandangan siswa tehadap matematika. Lembar angket yang digunakan juga sudah terlebih di uji validitas dan reliabilitasnya. Sebelum data hasil pengisian angket skala disposisi matematis di uji menggunakan uji-t berpasangan, data terlebih dahulu ditransformasikan dengan menggunakan metode Method of successive interval (MSI). Pengolahan data menggunakan bantuan program Microsoft Office Excel 2007 dan software Statistical Package for the Social Science (SPSS) versi 16.

\section{HASIL PENELITIAN DAN PEMBAHASAN}

Perkembangan disposisi matematis siswa ditinjau dari seberapa besar perbedaan rata-rata disposisi matematis siswa sebelum dan sesudah proses pembelajaran dengan pendekatan problem posing berlangsung Berikut disajikan hasil analisis deskriptif data disposisi matematis sebelum pembelajaran dengan pendekatan problem posing berlangsung (disposisi awal) dan sesudah pembelajaran dengan pendekatan problem

Tabel 1. Analisis Statistik Deskriptif Data Disposisi Matematis Sebelum dan Sesudah Pembelajaran dengan Pendekatan Problem Posing

\begin{tabular}{|l|c|c|c|l|l|r|}
\hline & & & & & $\begin{array}{l}\text { Std. } \\
\text { Deviati } \\
\text { on }\end{array}$ & Varianc \\
& $\mathrm{N}$ & $\begin{array}{c}\text { Mi } \\
\mathrm{n}\end{array}$ & $\begin{array}{c}\text { Ma } \\
\mathrm{x}\end{array}$ & Mean & $\mathrm{e}$ \\
\hline disp & & 9 & & & & \\
osisi & & 8. & & & & \\
_awa & 2 & 0 & 141 & 1.171 & 11.1171 & \\
\hline 1 & 4 & 8 & .71 & $8 \mathrm{E} 2$ & & 123.591 \\
\hline disp & & & & & & \\
osisi & & 12 & & & & \\
akh & 2 & 1. & 152 & 1.334 & & \\
ir & 5 & 37 & .36 & $1 \mathrm{E} 2$ & 8.29055 & 68.733
\end{tabular}

Hasil analisis deskriptif $\mathrm{N}$-gain pada tabel di atas diperoleh rata-rata disposisi matematis siswa sesudah pembelajaran (disposisi akhir) lebih tinggi daripada ratarata sebelum pembelajaran (disposisi awal). Rata-rata disposisi awal siswa adalah $1.1718 \mathrm{E} 2$ atau 117,18 sedangkan disposisi akhir 1.3341E2 atau 133,41. Namun 
demikian, untuk membuktikan apakah nilai rata-rata tersebut berbeda secara signifikan maka diperlukan uji statistik lebih lanjut. Uji perbedaan rata-rata yang digunakan dalam hal ini adalah uji-t berpasangan atau PairedSamples $T$ Test. Sebelum data di uji menggunakan uji-t berpasangan, terlebih dahulu dilakukan prasayaratnya yaitu uji normalitas data. Berikut disajikan hasil pengujian normalitas data.

Tabel 2. Uji Normalitas Data

\begin{tabular}{|l|c|c|c|}
\hline & \multicolumn{3}{|c|}{ Kolmogorov-Smirnov ${ }^{\mathrm{a}}$} \\
\hline & Statistic & $\mathrm{df}$ & Sig. \\
\hline $\begin{array}{l}\text { disposisi_a } \\
\text { wal }\end{array}$ & .080 & 23 & $.200^{*}$ \\
\hline $\begin{array}{l}\text { disposisi_a } \\
\text { khir }\end{array}$ & .120 & 23 & $.200^{*}$ \\
\hline
\end{tabular}

Tabel 2 di atas menunjukkan bahwa nilai signifikansi yang diperoleh kedua kelompok data adalah 0,20 atau lebih dari 0,05 . Hal ini berarti kedua kelompok data tersebut berdistribusi normal. Dikarenakan syarat kenormalan data sudah terpenuhi, maka selanjutnya akan dilakukan uji perbedaan rata-rata menggunakan uji-t berpasangan. Hasil perhitungan uji perbedaan rata-rata dilakukan dengan bantuan SPSS versi 16 pada taraf signifikansi $\alpha=0,05$ dan kriteria pengujian adalah terima H0 jika nilai sig. $\geq \alpha$ (Uyanto, 2009). Adapun hipotesis penelitiannya adalah sebagai berikut:

H0: Tidak terdapat perbedaan yang signifikan tingkatan disposisi matematis siswa SMP sebelum dan sesudah memperoleh pembelajaran melalui pendekatan problem posing..

Ha: Terdapat perbedaan yang signifikan tingkatan disposisi matematis siswav SMP sebelum dan sesudah memperoleh pembelajaran melalui problem posing.
Berikut disajikan hasil pengujian data disposisi matematis sebelum dan sesudah pembelajaran dengan menggunakan uji-t berpasangan atau Paired-Samples T Test.

Tabel 3. Uji Perbedaan Rata-rata Data Disposisi Matematis Sebelum dan Sesudah Pembelajaran dengan Pendekatan Problem Posing.

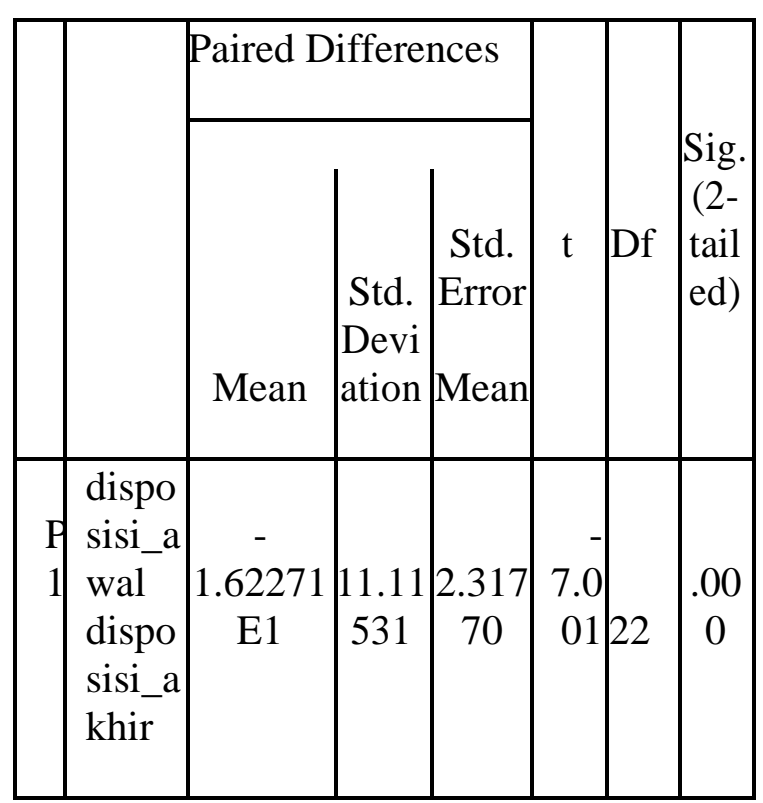

Tabel 3 di atas menunjukkan bahwa nilai sig. (2-tailed) adalah 0.00 atau kurang dari dari taraf signifikansi yang telah ditetapkan yaitu 0,05 sehingga berdasarkan kriteria pengujian maka $\mathrm{H} 0$ ditolak atau terima Ha. Hal ini berarti terdapat perbedaan yang signifikan tingkatan disposisi matematis siswa SMP sebelum dan sesudah memperoleh pembelajaran melalui pendekatan problem posing.

Berdasarkan tabel 3 juga dapat diketahui bahwa selisih rata-rata disposisi matematis siswa adalah sebesar -1.62271E1 atau $-16,227$, dimana nilai rata-rata disposisi matematis yang siswa sebelum dan sesudah pembelajaran adalah 117,18 dan 133,41 , sehingga dapat disimpulkan bahwa disposisi matematis siswa menjadi lebih baik setelah mereka memperoleh pembelajaran dengan pendekatan problem posing. Hasil ini sesuai dengan hasil yang didapat dalam penelitian Syaban (2009), Wardani (2009), dan 
Kesumawati (2012) yang menyimpulkan bahwa secara keseluruhan peningkatan disposisi matematis siswa yang memperoleh pembelajaran dengan model atau pendekatan tertentu lebih baik dibandingkan dengan siswa yang memperoleh pembelajaran konvensional. Faktor pendekatan pembelajaran merupakan salah satu faktor yang sangat berpengaruh dalam meningkatkan disposisi atau sikap positif siswa terhadap matematika. Penerapan pendekatan yang tepat seperti pendekatan problem posing dalam proses pembelajaran akan membuat siswa menjadi lebih tertarik kepada matematika dan akan lebih bertanggung jawab dalam menyelesaikan masalah-masalah matematika. Hal ini sesuai dengan pendapat English (1997) yang menyatakan bahwa membuat soal dapat meningkatkan kemampuan berpikir siswa dan dapat membantu siswa dalam mengembangkan keyakinan dan kesukaan terhadap matematika.

Berdasarkan pengamatan peneliti ketika berlangsungnya proses pembelajaran dengan pendekatan problem posing, sebagian besar siswa terlihat antusias ketika merancang soal dari situasi yang diberikan walaupun ada beberapa juga yang terlihat hanya menerima saja apa yang dikerjakan oleh temannya. Bahkan pada pertemuan kedua, ketiga dan keempat, mereka mulai terlihat menikmati proses pembelajaran yang baru dan mulai berani mengemukakan pendapat serta terlihat semakin percaya diri dan lebih gigih dalam mengajukan soal dan membuat penyelesaian untuk soal tersebut. Secara umum siswa yang mendapat pembelajaran dengan pendekatan problem posing memiliki kecendrungan yang positif terhadap disposisi matematis. Misalnya bertekad kuat untuk menyelesaikan tugas matematika secara bersama dalam kelompoknya, ketertarikan dan keinginan untuk menemukan sesuatu yang baru, hal ini dapat dilihat dari aktifitas siswa dalam merancang soal yang berhubungan dengan bangun datar segiempat.
DAFTAR PUSTAKA

Abdurrahman, M. (1999). Pendidikan bagi Anak Berkesulitan Belajar. Jakarta: Rineka Cipta.

Arikunto, S. (2000). Manajemen Penelitian. Jakarta: Rineka Cipta

English, L. D. (1997). Promoting a Problem Posing Classroom. Teaching Children Mathematics Journal, 4(3), 172-179. Diakses pada tanggal 20 Mei 2013 dari www. eric.ed.gov.

Karlimah. (2010). Pengembangan

Kemampuan Komunikasi dan

Pemecahan Masalah serta Disposisi

Matematis Mahasiswa PGSD Melalui

Pembelajaran Berbasis Masalah.

Diakses pada tanggal 22

Januari 2016 pada http://www.pdfarchive.com/2011/03/16/73- karlimah/.

Katz, L. G. (1993). Dispositions as Educational Goals. ERIC Digest. Diakses pada tanggal 20 Desember 2015 dari www.eric.ed.gov.

Kesumawati, Nila. (2012). Disposisi Matematis. Diakses pada tanggal 11 Januari $2016 \quad$ dari http://staff.uny.ac.id

Mahmudi, A. (2010). Tinjauan Asosiasi antara Kemampuan Pemecahan Masalah Matematis dan Disposisi Matematis. Makalah Disajikan pada Seminar Nasional Pendidikan Matematika FMIPA UNY, 17 April 2010.

MKBPM. (2001). Srategi Pembelajaran Matematika Kontemporer. Bandung: JICA-Universitas Pendidikan Indonesia (UPI).

NCTM, (2003). Principles and Standarts for School mathematics. Diakses pada 
tanggal 8 Desember 2012 dari http://www.ncate.org.

Silver, E.A. (1994). On Mathematical Problem Posing, For the Learning of Mathematics, 14(1), 19-28. Diakses pada tanggal 23 Desember 2013 dari www.jstor.org

Sumarmo, U. (2010). Berfikir dan Disposisi Matematik: Apa, Mengapa, dan Bagaimana Dikembangkan pada Peserta Didik. Diakses pada tanggal 7 Oktober $2015 \quad$ dari http://math.sps.upi.edu/?p=58

Syaban, M. (2009). Menumbuh kembangkan Daya dan Disposisi Matematis Siswa
Sekolah Menengah Atas Melalui Pembelajaran Investigasi. Matematis Siswa. EDUCATIONIST, III (2), 129-136

Uyanto. Stanislaus S. (2009). Pedoman Analisis Data dengan SPSS. Yogyakarta: Graha Ilmu.

Wardani, S. (2009). Meningkatkan kemampuan berfikir kreatif dan disposisi matematik siswa SMA melalui pembelajaran dengan pendekatan model Sylver. Disertasi doktor, tidak diterbitkan. Sekolah Pascasarjana Universitas Pendidikan Indonesia: Bandung 